\title{
Transmission of infectious pancreatic necrosis virus from carrier striped bass to brook trout
}

\author{
K. W. McAllister ${ }^{1}$, P. E. McAllister ${ }^{2, *}$ \\ ${ }^{1}$ US Fish and Wildlife Service, Fish Culture Research Laboratory, Box 700, Kearneysville, West Virginia 25430, USA \\ ${ }^{2}$ US Fish and Wildlife Service, National Fish Health Research Laboratory, Box 700, Kearneysville, West Virginia 25430, USA
}

\begin{abstract}
Waterborne infectivity trials were conducted to determine if infectious pancreatic necrosis virus could be transmitted from virus-carner striped bass Morone saxatilis to brook trout Salvelinus fontinalis. When 29 - and 49-d-old brook trout were held in tanks downstream from the carrier striped bass, $19 \%$ of the brook trout that died yielded the virus at titers of $10^{2}$ to $10^{4}$ plaque-forming units per $\mathrm{g}$ tissue. Three mo after the transmission trials, some of the surviving brook trout continued to carry virus and to produce virus-neutralizing antibodies
\end{abstract}

\section{INTRODUCTION}

Federal and state agencies in the USA are actively engaged in the hatchery propagation of striped bass Morone saxatilis to augment declining populations in Chesapeake Bay (Maryland). Wild striped bass broodstock are captured and spawned, and the progeny are reared to fingerling size for release into bay tributaries. Infectious pancreatic necrosis virus (IPNV) has been isolated from the sex products of wild broodstock and on one occasion from hatchery-reared striped bass (Schutz et al. 1984). The virus is not a significant pathogen of striped bass, but the fish can become long-term virus carriers (Wechsler et al. 1986, Wechsler et al. 1987). Earlier laboratory studies showed that the striped bass isolate of IPNV is serotype VR-299 and is highly virulent for brook trout Salvelinus fontinalis (McAllister \& Owens unpubl.). Because some striped bass are being reared at salmonid hatcheries, we investigated whether IPNV-carrier striped bass pose a potential threat to salmonids (in this case, brook trout). We therefore conducted tests to determine whether waterborne transmission of virus from carrier striped bass to trout occurred. Trout surviving the transmission trials were also monitored for carrier prevalence and for virus-neutralizing antibody production.

\footnotetext{
- Addressee for correspondence
}

\section{MATERIALS AND METHODS}

Cell culture and virus. Chinook salmon embryo (CHSE-214) cells were grown at $18^{\circ} \mathrm{C}$ in Eagle's minimum essential medium (MEM) containing $10 \%$ fetal bovine serum, $100 \mathrm{IU} \mathrm{m}^{-1}$ penicillin, and $100 \mu \mathrm{g}$ $\mathrm{ml}^{-1}$ streptomycin. The IPNV, originally isolated from moribund striped bass (Schutz et al. 1984), was passaged twice in CHSE-214 cells and aliquots were stored at $-70^{\circ} \mathrm{C}$. The virus was titered by plaque assay as described by Wolf \& Quimby (1973). Before use, the virus was diluted in phosphate-buffered saline (PBS, $\mathrm{pH}$ 7.2) to achieve the desired concentration.

Fish. All fish were obtained from culture stations having histories of freedom from IPNV. Striped bass, originally obtained as fingerlings from Harrison Lake National Fish Hatchery (Virginia, USA), were reared at the National Fish Health Research Laboratory and the Fish Culture Research Laboratory and were 1 to 3 yr old at the time of the transmission trials. Brook trout fry (20 d old) were obtained from White Sulphur Springs National Fish Hatchery (West Virginia, USA). Striped bass fingerlings and brook trout fry were assayed as described below and found to be free of IPNV. For all phases of culture and challenge, striped bass and brook trout were held in IPNV-free spring water at $12{ }^{\circ} \mathrm{C}$. The striped bass were fed virus-free fingerling rainbow trout Salmo gairdneri, and brook trout were fed com- 
mercial trout food at the production level allotment (McAllister \& Owens 1986).

Preparation of IPNV-carrier striped bass. Three groups of virus-carrier striped bass used in our trials were prepared essentially as described by Wechsler et al. (1986). One group of fish was injected intraperitoneally with $10^{6}$ plaque-forming units (PFU) of the striped bass IPNV per fish; the second group was fed brook trout fry carrying $10^{5}$ to $10^{6} \mathrm{PFU}$ of virus per fish; and the third group had been challenged with the striped bass IPNV isolate the previous year and still carried $10^{2}$ to $10^{3} \mathrm{PFU}$ of virus per $\mathrm{g}$ of tissue. Negative control striped bass were injected intraperitoneally with PBS.

At 3 and 4 wk post-exposure, assays of the striped bass indicated that virus-injected fish carried about $10^{4}$ PFU $\mathrm{g}^{-1}$ tissue and those fed virus-infected fish carried about $10^{3} \mathrm{PFU} \mathrm{g}^{-1}$ tissue.

Waterborne transmission challenge of brook trout. Details of the procedures used for showing that striped bass carrying IPNV are infective for brook trout are given in Tables 1 and 2 . The general procedure involved distributing the infected striped bass evenly in the 2 top tanks of a 3 -tank cascade flow system and placing the brook trout downstream of them in the third tank so that water from the virus carrier bass flowed over the trout. The tanks, each of 15 l capacity, were supplied with spring water at $12^{\circ} \mathrm{C}\left(1 \mathrm{l} \mathrm{min}^{-1}\right)$. Two trials were conducted: the first used 29 -d-old trout; the second, 49-d-old trout. In both trials the trout were monitored for $60 \mathrm{~d}$. Dead fish were collected daily and assayed individually for virus, some being held at $-20^{\circ} \mathrm{C}$ for $5 \mathrm{~d}$ before being assayed for virus.

Negative control brook trout from the same source as those used in the infectivity trials were also included in the trials. These trout were held in a manner identical to those in the infectivity trials except that they were exposed to effluent from IPNV-free striped bass that had been injected intraperitoneally with PBS. The negative controls were also observed for $60 \mathrm{~d}$, and mortalities were assayed for virus.

Positive control brook trout were challenged using the standard immersion exposure protocol described by McAllister \& Owens (1986) to demonstrate the susceptibility of the brook trout and the virulence of the striped bass IPNV isolate. Briefly, the challenge involved exposing the trout to $10^{5} \mathrm{PFU} \mathrm{ml}^{-1}$ of IPNV for 5 h at $12^{\circ} \mathrm{C}$.

Virus assay. Fish were assayed individually for virus. For fry, whole viscera were assayed, and for larger fish, kidneys, liver, spleen, and caeca were pooled for assay. Samples were weighed, homogenized to a paste with a mortar and pestle, and suspended at a 1:10 dilution (wt/vol.) in PBS containing $100 \mathrm{IU} \mathrm{ml}^{-1}$ penicillin and $100 \mu \mathrm{g} \mathrm{ml}^{-1}$ streptomycin. Samples were centrifuged at $1500 \times g$ for $20 \mathrm{~min}$ at $4{ }^{\circ} \mathrm{C}$. The supernatant fluid was removed, diluted with $\mathrm{PBS}$, and assayed for virus by the plaque method of Wolf \& Quimby (1973). Replicate monolayers of CHSE-214 cells were each inoculated with $0.1 \mathrm{ml}$ of diluted sample, incubated at $18^{\circ} \mathrm{C}$ for $1 \mathrm{~h}$ for virus adsorption, and overlaid with medium containing agarose. After incubation for $48 \mathrm{~h}$ at $18^{\circ} \mathrm{C}$, the cultures were fixed and stained, and the plaques enumerated. Virus titer was expressed as PFU $\mathrm{g}^{-1}$ tissue.

Neutralizing antibody assay. Plasma samples were taken from brook trout in each exposure group. We anesthesized fish with tricaine methanesulfonate, and collected blood from the caudal vessel in a heparinized microhematocrit capillary tube. The samples were centrifuged, and the plasma fractions collected. The plasma was diluted 1:100 (vol./vol.) in PBS, heated at $56^{\circ} \mathrm{C}$ for $30 \mathrm{~min}$, and stored at $4^{\circ} \mathrm{C}$. We have subsequently compared virus-neutralizing activity in brook trout serum heat-inactivated at $45^{\circ} \mathrm{C}$ with that heated at $56^{\circ} \mathrm{C}$ and found no significant difference between the heat treatment groups.

Table 1. Salvelinus fontinalis. Recovery of infectious pancreatic necrosis virus (IPNV) from 29-d-old brook trout that died during $60 \mathrm{~d}$ of exposure to various groups of virus-carrier striped bass Morone saxatilis. Brook trout were exposed to the effluent from 10 parenterally infected, 10 orally infected, or 41 -yr virus-carrier striped bass. Each tank of brook trout contained 100 fish. Negative control brook trout were taken from the same population as those for the exposure trials. The control tank contained 100 fish which were maintained downstream of IPNV-free striped bass. During the $60 \mathrm{~d}$ trial, 10 negative control fish died, but no virus was isolated. No fish died in the tanks holding untreated stock brook trout

\begin{tabular}{lccc}
\hline & & IPNV-carrier striped bass group & 1-yr carriers \\
\hline Day virus first isolated & Injected & Oral & 8 \\
Number of virus-positive fish/total mortality & 8 & 12 & $5 / 18$ \\
Virus titer $^{\text {A }}$ & $10^{2}-10^{4}$ & $1 / 52$ & $10^{2}-10^{3}$ \\
Average titer & $4.0 \times 10^{3}$ & $3.1 \times 10^{3}$ & $3.2 \times 10^{3}$ \\
a Virus titers are expressed as plaque-forming units per gram of tissue (PFU g ${ }^{-1}$ tissue) & \\
\hline
\end{tabular}


To assay for neutralizing antibody, we mixed equal volumes of diluted virus and plasma, incubated the mixture at $18^{\circ} \mathrm{C}$ for $1 \mathrm{~h}$, and assayed it for residual infectivity using 96-well plates as described by Amos (1985). Virus titer was calculated by the method of Reed \& Muench (1938), and the $\log _{10}$ of the neutralization index (LNI) determined as described by Rovozzo \& Burke (1973).

\section{RESULTS}

In the transmission trial with 29 -d-old brook trout, we first recovered IPNV from fish that died $8 \mathrm{~d}$ after exposure to the injected carrier striped bass, $8 \mathrm{~d}$ after exposure to the 1 -yr carriers, and $12 \mathrm{~d}$ after exposure to the orally infected striped bass (Table 1). Mortality continued sporadically in all 3 groups of brook trout during the $60 \mathrm{~d}$ of exposure. Overall $34 \%$ of the exposed brook trout died and virus was recovered from $14 \%$ of the dead fish. The average titer from the virus-positive trout was $3.4 \times 10^{3} \mathrm{PFU} \mathrm{g}^{-1}$ tissue. Similar results were obtained in the trial with 49 -d-old brook trout (Table 2). Virus was first recovered from dead fish $19 \mathrm{~d}$ after exposure. During the $60 \mathrm{~d}$ trial, $12 \%$ of the brook trout died and virus was recovered from $37 \%$ of the dead fish. The virus titer ranged from $10^{2}$ to $10^{3} \mathrm{PFU} \mathrm{g}^{-1}$ tissue.

After the $60 \mathrm{~d}$ trial, the exposed brook trout were moved to isolated tanks and held for an additional 3 mo at which time all of the fish that survived to this point (102 fish) were tested for virus-neutralizing antibody
Table 2. Salvelinus fontinalis. Recovery of infectious pancreatic necrosis virus (IPNV) from 49-d-old brook trout that died during $60 \mathrm{~d}$ exposure to virus-carrier striped bass Morone saxatilis. Brook trout were exposed to the effluent from 5 parenterally infected and 5 orally infected virus-carrier striped bass. The tank of brook trout contained 250 fish. Negative control brook trout were taken from the same population as those for the exposure trial. The control tank contained 100 fish, which were maintained downstream of IPN virus-free striped bass. During the $60 \mathrm{~d}$ trial, 1 negative control fish died, but no virus was isolated. No fish died in tanks holding untreated stock brook trout

\begin{tabular}{|lc|}
\hline & $\begin{array}{c}\text { IPNV-carrier } \\
\text { striped bass group } \\
\text { Injected + Oral }\end{array}$ \\
\hline Day virus first isolated & 19 \\
Number of virus-positive & $11 / 30$ \\
fish/total mortality & $10^{2}-10^{3}$ \\
Virus titer & $3.4 \times 10^{2}$ \\
average titer & Virus titers are expressed as plaque-forming units per \\
gram of tissue (PFU g & \\
\hline
\end{tabular}

and for virus carrier prevalence. Among the surviving exposed brook trout, $12 \%$ showed no IPNV-neutralizing antibody (LNI $=0), 67 \%$ had a LNI of 0.25 to 0.75 and $17 \%$ had a LNI of 1.0 to 2.0 (Table 3). No IPNVneutralizing antibody was detected in the negative control fish or in $24 \%$ of the positive control fish; however the LNI exceeded 1.75 in $76 \%$ of the positive control fish. All fish from the transmission trials assayed for neutralizing antibody were also assayed for infec-

Table 3. Salvelinus fontinalis. Virus-neutralizing antibody in brook trout exposed to striped bass Morone saxatilis carrying infectious pancreatic necrosis virus (IPNV). Brook trout were exposed to effluent water from tanks holding IPNV-carrier striped bass. Brook trout were $29 \mathrm{~d}$ old in Trial 1 and $49 \mathrm{~d}$ old in Trial 2. Transmission trials were $60 \mathrm{~d}$ in duration. Surviving brook trout were held in isolated tanks an additional $90 \mathrm{~d}$ at which time those fish still living (102 fish) were assayed for plasma virusneutralizing activity. Brook trout survivors from Trial 1 were about $180 \mathrm{~d}$ old when assayed for plasma virus-neutralizing activity, and those from Trial 2 were about $200 \mathrm{~d}$ old

\begin{tabular}{|c|c|c|c|c|}
\hline \multirow[t]{2}{*}{ Brook trout exposure group } & \multicolumn{4}{|c|}{$\log _{10}$ neutralization index (LNI) } \\
\hline & 0 & $0.25-0.75$ & $1.0-1.5$ & $\geq 1.75$ \\
\hline \multicolumn{5}{|l|}{ Trial 1} \\
\hline Parenterally infected carriers ${ }^{\mathrm{c}}$ & 2 & 22 & 2 & 0 \\
\hline Orally infected carriers ${ }^{a}$ & 1 & 15 & 4 & 0 \\
\hline $1-y r$ carriers ${ }^{a}$ & 6 & 11 & 0 & 1 \\
\hline \multicolumn{5}{|l|}{ Trial 2} \\
\hline Parenterally \& orally infected carriers ${ }^{a}$ & 3 & 23 & 12 & 0 \\
\hline Negative controls ${ }^{b}$ & 20 & 0 & 0 & 0 \\
\hline Positive controls ${ }^{c}$ & 4 & 0 & 0 & 13 \\
\hline \multicolumn{5}{|c|}{${ }^{a}$ Carriers: striped bass carrying IPNV } \\
\hline \multicolumn{5}{|c|}{$\begin{array}{l}\text { b Negative control brook trout from Trials } 1 \text { and } 2 \text { were exposed to effluent water from striped bass injected intraperitoneally } \\
\text { with phosphate-buffered saline. Twenty of the surviving negative controls were tested for virus-neutralizing antibodies } \\
\text { c Positive controls were survivors of a laboratory chalienge performed on } 46449 \text {-d-old brook trout as described by McAllister } \& \\
\text { Owens (1986). All trout alive at } 5 \text { mo post challenge were tested for virus-neutralizing antibodies }\end{array}$} \\
\hline
\end{tabular}


tious virus: $8 \%$ of the fish were found to be IPNV carriers. The virus titers ranged from $10^{2}$ to $10^{3} \mathrm{PFU} \mathrm{g}^{-1}$ tissue (data not shown).

\section{DISCUSSION}

Our transmission trials showed that carrier striped bass shed IPNV that later infected young-of-the-year brook trout. Virus was recovered from 14 to $37 \%$ of the fish that died, and $8 \%$ of the survivors continued to carry virus. Mortality did not reach an epizootic level among the brook trout, probably because the virus concentration in the effluent water from the carrier striped bass was low. McAllister \& Owens (1986) observed that reductions in the titer of the challenge virus or in the duration of the challenge resulted in reductions in mortalities occurring in challenged brook trout. When we challenged brook trout with the striped bass IPNV using the more rigorous method of McAllister \& Owens (1986), mortality was approximately $94 \%$.

Most brook trout that survived the transmission trials developed detectable, albeit low, levels of virus-neutralizing antibody. Although the majority of the LNI values indicated a weak to questionable antibody response as judged by traditional criteria (Rovozzo \& Burke 1973), the values are probably significant because plasma samples were assayed at a 1:100 dilution and because no virus-neutralizing antibody was detected in negative control fish. The low levels of antibody may be the result of the low levels of virus prompting the response. Brook trout exposed to carrier striped bass with the lowest virus titer (the 1-yr carrier striped bass) also had the lowest overall LNI values. In $76 \%$ of the positive control fish that survived exposure to sufficient virus to cause epizootic-level mortality, LNI values were higher $(\geq 1,75)$.
We demonstrated that IPNV can be transmitted from a non-salmonid to a salmonid. Under our experimental conditions epizootic mortality did not occur, the level of virus-positive mortality was low, and the virus titers of the mortalities were lower than those usually associated with fish dying of infectious pancreatic necrosis. Notwithstanding this, it is clear that IPNV-infected striped bass pose a definite threat to salmonids when contact via the water supply is possible.

Acknowledgements. We thank P. H. Eschmeyer, J. G. Geiger, R. L. Herman, and C. L. Schultz for reviewing the manuscript and R. B. Owens for editorial assistance.

\section{LITERATURE CITED}

Amos, K. H. (1985). Procedures for the detection and identification of certain fish pathogens. 3rd edn. Fish Health Section, American Fisheries Society, Corvallis, Oregon

McAllister, P. E., Owens, W. J. (1986). Infectious pancreatic necrosis virus: protocol for a standard challenge to brook trout. Trans. Am. Fish. Soc. 115: 466-470

Reed, L. S., Muench, H. (1938). A simple method of estimating fifty percent endpoints. Am. J. Hyg. 27: 493-497

Rovozzo, G. C., Burke, C. N. (1973). A manual of basic virological techniques. Prentice-Hall, Inc., Englewood Cliffs, New Jersey

Schutz, M., May, E. B., Kraeuter, J. N., Hetrick, F. M. (1984). Isolation of infectious pancreatic necrosis virus from an epizootic occurring in cultured striped bass, Morone saxatilis (Walbaum). J. Fish Dis. 7: 505-507

Wechsler, S. J., Schultz, C. L., McAllister, P. E., May, E. B., Hetrick, F. M. (1986). Infectious pancreatic necrosis virus in striped bass Morone saxatilis: experimental infection of fry and fingerlings. Dis. Aquat. Org. 1: 203-208

Wechsler, S. J., Woods, L. C., Kraeuter, J. N., Hetrick, F. M., McAllister, P. E. (1987). Transmission of infectious pancreatic necrosis virus in striped bass, Morone saxatilis (Walbaum). J. Fish Dis. 10: 29-34

Wolf, K., Quimby, M. C. (1973). Fish viruses: methods for plaquing eight agents under normal atmosphere. Appl. Microbiol. 25: 659-664 